\title{
Learning in Biology
}

- maría josé apodaca, Joseph d.

MCINERNEY, OSVALDO E. SALA,

LILIANA KATINAS, JORGE V. CRISCI

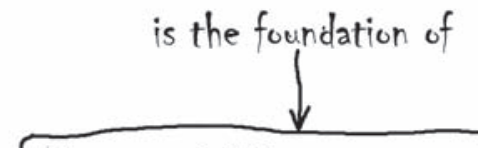

\begin{abstract}
Is it possible to teach biology without mentioning evolution? The answer is yes, but it is not possible for students to understand biology without the evolutionary context on which the meaning and intellectual value of biological concepts depend. Meaningful learning of evolution requires (1) that the students incorporate new knowledge into a cognitive structure linked with higher-order concepts; (2) a well-organized knowledge structure; and (3) a positive emotional attachment and identification (affective commitment) to the subject by the learner. Concept maps are useful tools in meaningful learning. We present a concept map that organizes concepts of history of life and the processes that generate it, and the hierarchical relationships among them. Biological evolution is a compelling account of life on Earth and of human origins. It constitutes a unifying explanatory framework that can generate a powerful affective commitment to the subject. The concept map provided here is tied to the Next Generation Science Standards (NGSS).
\end{abstract}

Key Words: Evolution; concept maps; tree of life; evolutionary processes; biology teaching.

\section{Introduction}

Is it possible to teach biology without mentioning evolution? The answer, unfortunately, is yes; it happens all the time, for reasons ranging from ideological opposition to teachers' discomfort with the content. It is not possible, however, for students to understand biology without the evolutionary context on which the meaning and intellectual value of biological concepts depend (Dobzhansky, 1973; McInerney, 2009). On the other hand, many introductory biology textbooks include evolution but present the information in a conceptually segregated manner (Nehm et al., 2009).
Meaningful learning, as described by Ausubel et al. (1978) and Novak (2002), requires the following elements:

(1) The incorporation of new knowledge into a cognitive structure linked with higher-order, more inclusive concepts.

(2) A well-organized and relevant knowledge structure.

(3) A positive emotional attachment and identification (affective commitment) to the subject by the learner. This affective commitment is necessary because learners' feelings enhance their capacity to make sense out of their experiences.

Therefore, meaningful learning in biology is possible only with evolution as a framework, because it is the only framework that organizes all of our observations and experiments about the living world into a cohesive, conceptual whole. On the other hand, biological evolution is a great and stirring account of life on Earth and of human origins within it. Therefore, evolution is not only a unifying and explanatory element but constitutes, in itself, a powerful affective commitment and identification to the subject.

Concept maps are excellent, meaningful vehicles for learners to organize and visualize ideas or concepts and hierarchical relationships among them (requirements 1 and 2 above). They help learners clarify their thinking and organize and prioritize new information (Novak, 2010). In this article, we present in summary form a concept map (comprising three figures) that shows the central concepts of evolutionary biology and their relationships to one another in an organized, relevant knowledge structure.

This article is not an educational experiment or a replacement for a textbook. It is an educational tool for teachers and learners, to be used as an introductory road map to the main concepts of evolutionary biology and the relationship among them. Existing concept maps in biology, some of which include evolutionary biology, reside in

The American Biology Teacher, Vol. 81, No. 2, pp. 79-87, ISSN 0002-7685, electronic ISSN 1938-4211. C2019 National Association of Bioloģy Teachers. All rights

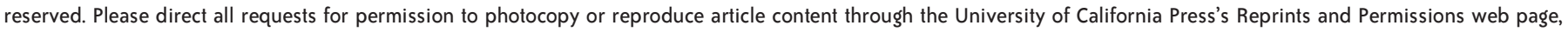
www.ucpress.edu/journals.php?p=reprints. DOI: https://doi.orģ/10.1525/abt.2019.81.2.79. 
websites (e.g., https://www.lucidchart.com/pages/examples/conceptmap/, https://prezi.com/ssbyu2lvllsp/biology-concept-maps/) and in the literature (e.g., National Academy of Sciences, 1998; Almond et al., 2015; Kong et al., 2017). Most of them, however, are too general or focus only on one topic of evolution, such as evolutionary trees or natural selection, or do not include the most recent advances in evolutionary research, such as genetic engineering. In addition, many of those concept maps were constructed by educators and not by researchers in evolution who also teach or have taught at the high school or university level. Therefore, we propose here a way to visualize main ideas about evolution in the context of the whole set of ideas, avoiding fragmented learning of each concept independently. In addition, the concept map presented here is updated with recent scientific advances in the discipline. We expect that the content of our concept map represents, in summary form, current knowledge in evolutionary biology, including the scientific controversies (e.g., the role of phenotypic plasticity in generating genetic changes) that will help students see the state of the art and the dynamics of the discipline. Also, these controversies may trigger valuable discussions in the classroom, fomenting the critical thinking of the learners.

The graphical structure will allow learners to follow the sequential flow of the patterns (history of life) and the processes that generate the patterns, as it happens in nature. We propose that the content and the graphical structure of the concept map can promote meaningful learning of evolutionary biology, because such learning occurs when relationships between concepts become more explicit, more precise, and better integrated with prior knowledge in biology (see below).

The narrative complements the map and serves as a kind of glossary with selected references. Superscript numerals relate the narrative to the most comprehensive ideas of the map.

This article is intended for precollege students and teachers. Precollege students might use the concept map to retrieve, review, or learn about evolution. Teachers could use the map for direct instruction, as a curriculum organizer, or even as an assessment tool.

\section{O The Scope of Evolution}

The problematic expansion of bacterial resistance to antibiotics and of weeds' resistance to herbicides, the morphological and molecular similarities between different groups of organisms, the unity of all living things reflected in nucleic acids, the extraordinary and astonishing biodiversity on Earth, the past written in fossils, and the position of Homo sapiens in the history of life are isolated facts that one can understand and relate to each other only in the light of biological evolution (Dobzhansky, 1973).

Biological evolution ${ }^{1}$ consists in the change of the hereditary characteristics of groups of organisms in the course of multiple generations (Futuyma \& Kirkpatrick, 2017). In a long-term perspective, evolution is the descent with modification of different lineages from a common ancestor. From a short-term perspective, it is the adaptation of populations to environmental challenges and changes. Therefore, evolution has two components: the ancestor-descendant relationship of the different lineages (history of life) and the processes that produced them.

For some time, there has been controversy about the importance to evolutionary theory of four factors: nongenetic inheritance (inclusive inheritance), phenotypic plasticity, developmental processes, and niche construction. For some biologists, these factors have the potential to change our view of evolution (Laland et al., 2014, 2015;
Noble, 2015). A different group of biologists has argued that these factors already have been accounted for in modern evolutionary theory and have not yet demonstrated that their inclusion merits major changes in our current evolutionary framework (Wray et al., 2014; Charlesworth et al., 2017; Futuyma, 2017). We include these four factors in our concept map, using cautious wording about their importance, but showing that they already are part of evolutionary theory.

\section{O Validation of the Concept Map}

We validated the concept map in three ways. First, we examined relevant literature on evolution (e.g., Darwin, 1859; Dobzhansky, 1973; Coyne, 2009; Futuyma \& Kirkpatrick, 2017) and phylogenetics (e.g., Felsenstein, 2004; Baum \& Smith, 2012). All the authors of this article are researchers and have published papers in high-impact journals, such as Nature, Proceedings of the National Academy of Sciences, and Science, on the theory and practice of biodiversity (e.g., Sala, 2001, 2003, 2016; Crisci, 2006, 2008), biogeography (e.g., Crisci et al., 2003; Crisci \& Katinas, 2009; Apodaca et al., 2015b), ecology (e.g., Huxman et al., 2004; Jobbágy \& Sala, 2014; Gherardi \& Sala, 2015; Sala, 2016), evolution (e.g., Crisci, 1981, 1982; Barreda et al., 2010; Katinas et al., 2013), phylogenetics (e.g., Crisci \& Stuessy, 1980; Katinas \& Crisci, 2000; Apodaca et al., 2015a), and teaching about evolution (e.g., McInerney, 1989, 2009; Crisci et al., 1993, 2014; National Academy of Sciences, 1998; Andrews et al., 2002; Crisci \& Katinas, 2011).

Second, we consulted experts in evolution (e.g., Douglas Futuyma and Edgardo Ortiz-Jaureguizar) and used our own expertise as high school and university teachers (in some cases more than 40 years of teaching) in the following subjects: biodiversity, biogeography, biology education, conservation, ecology, evolution, multivariate analysis, phylogenetics, plant morphology, plant systematics, and taxonomy. This collective expertise was very useful in the construction of the concept map, allowing us to overcome the most common difficulties (such as troubles in linking new knowledge with higher-order, more inclusive concepts in cognitive structure) and answer fundamental student questions.

Third, to validate the concept map, we aligned it with the Next Generation Science Standards (NGSS), as explained below.

\section{Alignment of the Concept Map with NGSS}

The concept map is intended for use in middle school and high school and is based on the statement that "scientific knowledge assumes an order and consistency in natural systems" (NGSS Lead States, 2013). The map also aligns with seven life-sciences core ideas of the NGSS: interdependent relationships in ecosystems, inheritance and variation of traits, biodiversity, natural selection, adaptation, evidence of common ancestry, and fossils as evidence of the history of life. Figure 1 shows grades and standards that include those seven core ideas. The standards from first to fifth grades represent the prior knowledge that anchors the concept map. The map implicitly addresses crosscutting concepts such as patterns, cause and effect, systems and systems models, and stability and change. 


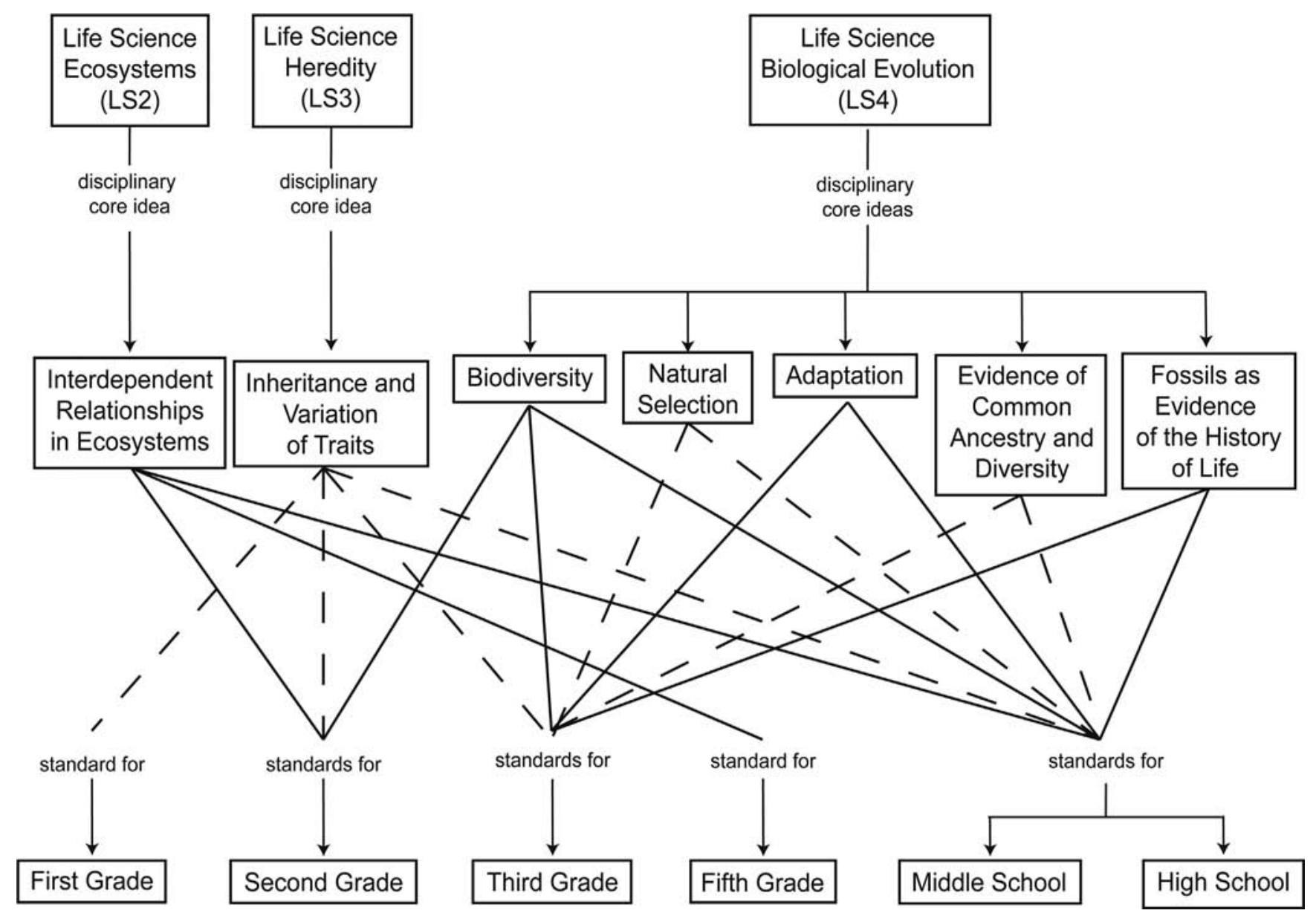

Figure 1. Life science core ideas of the NGSS that are addressed in the concept map.

\section{Central Concepts of Evolutionary Biology}

We built the concept map as follows:

(1) We identified three focus questions according to the current knowledge in evolution (Futuyma \& Kirkpatrick, 2017) and the idea of meaningful learning (Ausubel et al., 1978; Novak, 2002). We established as our first question, How should students understand evolutionary biology to foster meaningful learning? There is sound evidence that evolution has occurred and occurs now in the history of life. Among that evidence are the fossil record, the unity of life, observed evolution, vestigial structures, studies of comparative anatomy, and the spatial distribution of organisms. The evidence led us to the following two questions: What is the history of life? and What processes, in mutual influence with the interaction among organisms and their environment, generated the history of life? Most important, we wondered how students can incorporate the answers to these three questions into wellorganized and relevant knowledge.

(2) Guided by these questions, we identified what we consider the most pertinent concepts in evolution.

(3) We established a top-down hierarchical structure, giving the concepts at the top a more inclusive category (e.g., evolutionary biology studies biological evolution, biological evolution generates biodiversity, biological evolution is a consequence of interactions and processes) and following a sequential flow of events, as it happens in nature.

(4) Each concept appears only once in the concept map.

(5) We connected the concepts with a few linking words.

(6) Although some cross-links could be specified among several concepts, for the purpose of clarity we established only the most relevant cross-links to maintain the hierarchical structure.

(7) For learning purposes, an activity subsequent to the presentation of this concept map could include identification of cross-links among concepts to reveal a structure that is more a net than a hierarchy.

\section{How Should Students Understand Evolutionary Biology to Foster Meaningful Learning?}

Biological evolution generates biodiversity throughout the course of life's history (including the present) and as a consequence of processes at the population level in interaction with the environment (Figure 2).

\section{What Is the History of Life?}

The second question (Figure 3) is answered by reconstructing the genealogy of life (= phylogeny) ${ }^{2}$. Charles Darwin was one of the first naturalists to suggest, in his notebooks in 1837 (Notebook B, 


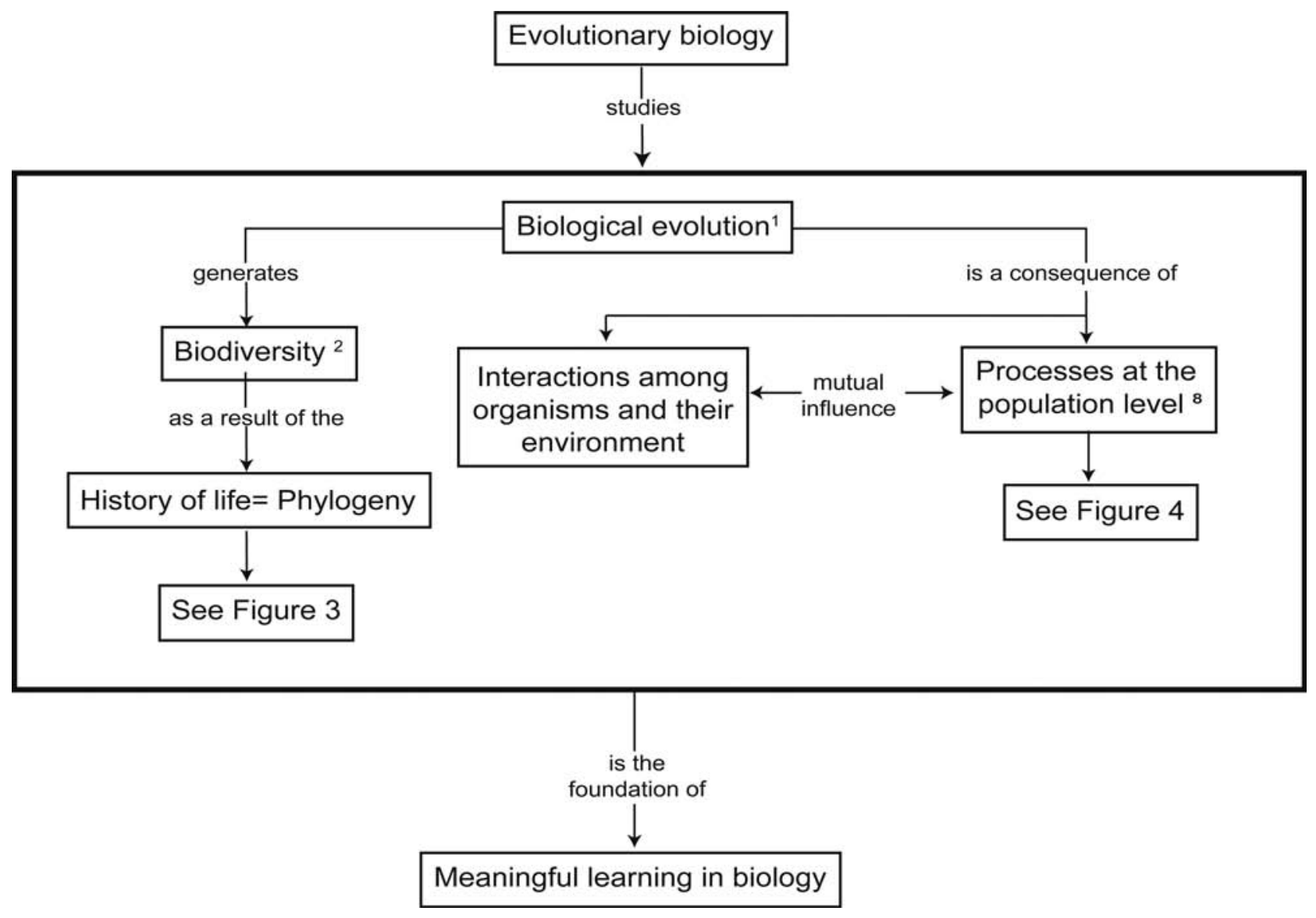

Figure 2. Concept map of evolutionary biology showing the two components of evolution: history of life and processes that generated it.

now stored in Cambridge University Library), the image of a family tree to represent the history of life. The only illustration in On the Origin of Species (Darwin, 1859) is a hypothetical tree of life.

Life on Earth came from a common ancestor more than 3.5 billion years ago; it then branched out over time, generating many new and diverse species reflected in the phylogeny of life (Coyne, 2009). The history of life has always been influenced by the history of the Earth ${ }^{3}$. Fossils (remains or evidence of life $>5000$ years old) are traces of that past and are a fundamental element for establishing the minimum age of groups and the rates of evolution of each (Pascual \& OrtizJaureguizar, 2007; Wyse Jackson, 2010). Fossils also reveal the phenomenon of extinction (disappearance of all members of a group of living beings), a fact common in the history of life (Lomolino et al., 2010).

Currently, scientists reconstruct the history of life by using phylogenetic methods, which are based on the character distribution of organisms and on applying homology ${ }^{4}$ as evidence of common ancestry. Homologous characters are those that originated, with or without modification, from the common ancestor of that group (Hall, 1994). The most widely used techniques of phylogenetic reconstruction ${ }^{5}$ are parsimony, maximum likelihood, and Bayesian inference (Felsenstein, 2004; Baum \& Smith, 2012).

Phylogenetic trees ${ }^{6}$ are active hypotheses about order in nature and, as such, are refined or amended through continued research (e.g., the finding of new characters). The phylogenetic tree of the different groups of organisms is assembled to build a hypothesis about the tree of life (Hillis, 2010).

Furthermore, phylogenetic trees are the basis of classifications $^{7}$ that have explanatory and predictive power because they reflect the generative system responsible for the observed attributes of the organism: biological evolution (Crisci et al., 2014). These classifications provide a reference system for the whole of biology (Crisci, 2006).

\section{What Processes, in Mutual Influence with the Interaction among Organisms and Their Environment, Generated the History of Life?}

The first step in answering this third question is to investigate the mechanisms of evolution (Figure 4).

The mechanisms at the population level ${ }^{8}$ are subject to the interaction of organisms with their environment ${ }^{9}$ (Pianka, 2011). These processes generate genetic change and are due mainly to three well-settled mechanisms - mutation, genetic recombination, and gene flow (Futuyma \& Kirkpatrick, 2017); and two mechanisms whose importance is still a matter of debate - nongenetic inheritance and phenotypic plasticity.

Mutation ${ }^{10}$ is the alteration of a gene whether or not it generates a change in the characteristics of the organism (Hamilton, 2009).

Genetic recombination ${ }^{11}$ shuffles the genes of both parents during sexual reproduction. It does not change the frequency of genes in the 


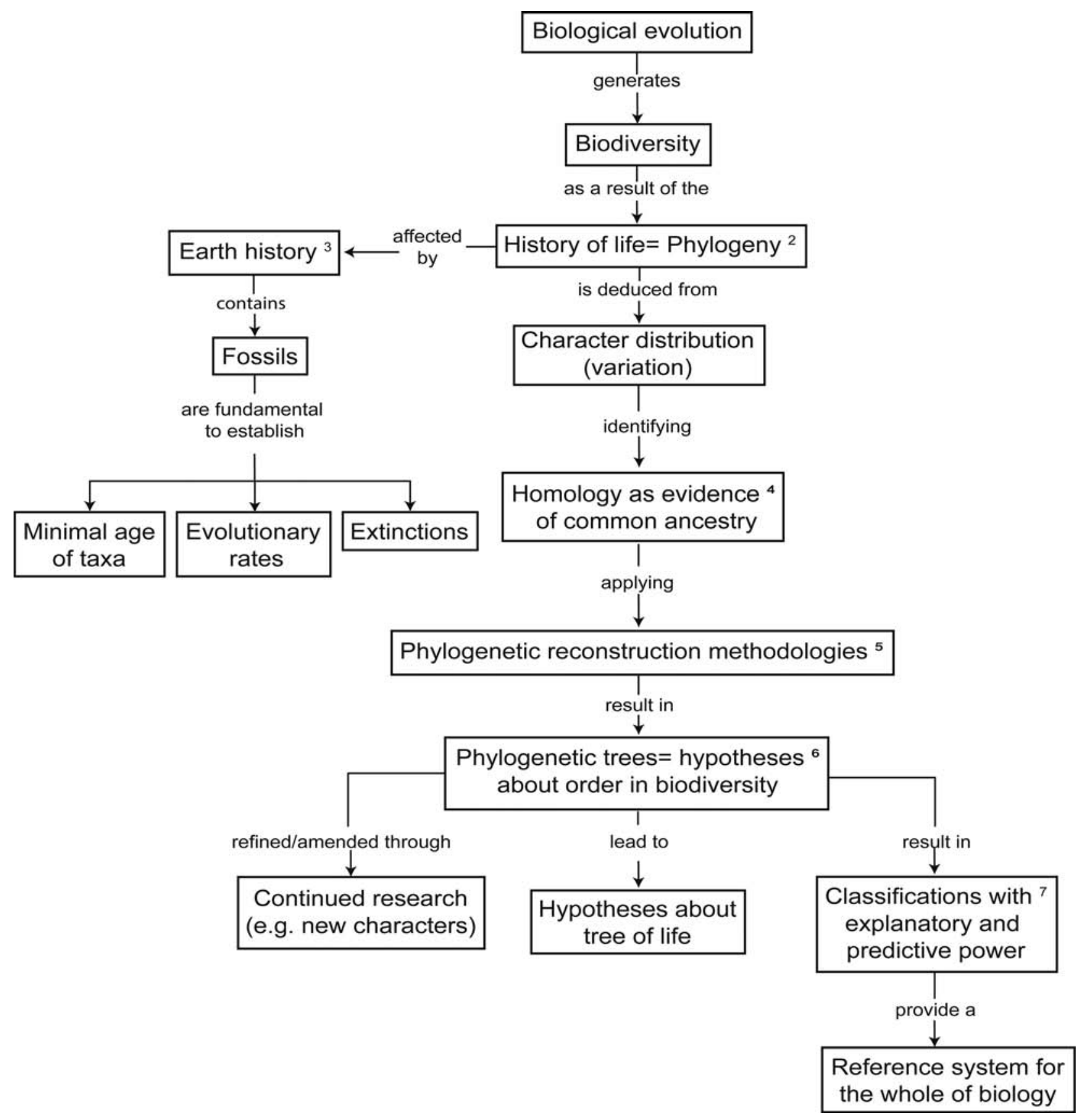

Figure 3. Part of the concept map showing the reconstruction of the history of life.

population, but it does produce new combinations of genes (Ridley, 2004). Gene mixing also occurs during crossing over in meiosis, prior to sexual reproduction (Futuyma \& Kirkpatrick, 2017).

Gene flow ${ }^{12}$ is the change in gene frequency in a population resulting from new genes introduced by the arrival of individuals from other populations (Templeton, 2006).

Nongenetic inheritance ${ }^{13}$ comprises changes in genetic information that do not involve alteration of the DNA (or RNA) sequence of a genome. At least three mechanisms contribute to nongenetic inheritance: (1) epigenetic inheritance, such as the DNA methylation that often reduces or eliminates gene transcription (Zenk et al., 2017); (2) parental effects that occur when the genotype or phenotype of the parents directly influences the phenotype of their offspring; and (3) cultural inheritance that is transmitted by behavior and learning (Jablonka \& Raz, 2009; Futuyma \& Kirkpatrick, 2017).

Phenotypic plasticity ${ }^{14}$ is the capacity of a genotype (the set of genes possessed by an individual organism) to generate any of several phenotypes (the characteristics of an organism produced by the interaction of its genes with the environment) depending on the environment. Some evolutionary biologists hold that phenotypic plasticity can precede genetic changes (West-Eberhard, 2003; Laland et al., 2015).

These five basic processes generate heritable variation, which in turn is subject to processes that may change the frequencies of genes and phenotypes in populations. These processes include genetic drift and natural selection. 


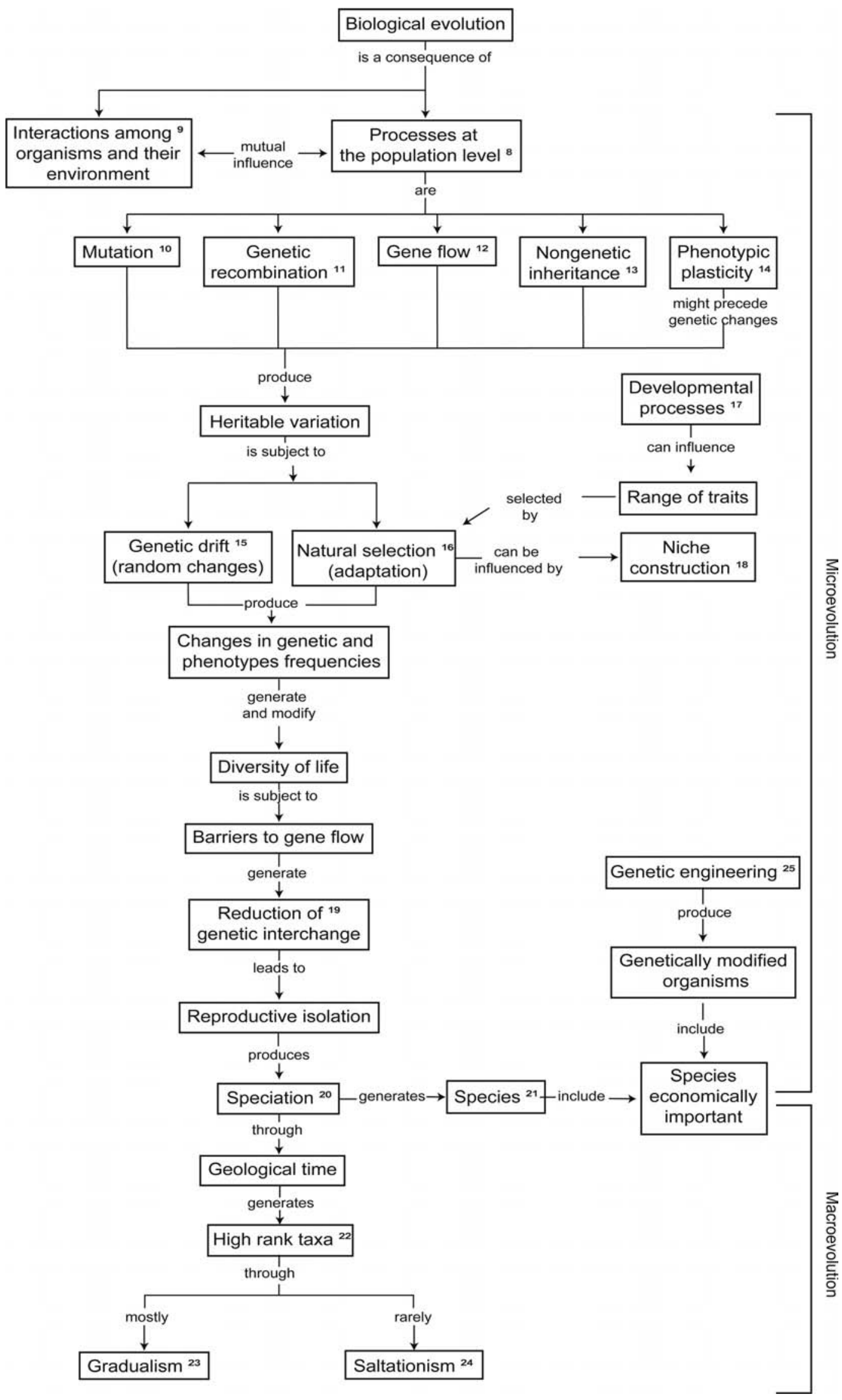

Figure 4. Part of the concept map showing what processes, in mutual influence with the interaction among organisms and their environment, have generated the history of life. 
Genetic drift ${ }^{15}$ is represented by random, nonadaptive changes in the frequency of two or more genotypes within a single population because of fluctuations due to "errors of sampling" (random processes; Graur \& Li, 2000). An example is the so-called "bottleneck" process (Templeton, 2006; Futuyma \& Kirkpatrick, 2017), whereby a small number of individuals from a population migrate and establish themselves as settlers (founders) of a new population. Because the founders represent only a small sample of the original population, the frequencies of genotypes in the new population may differ by chance from those of the source population.

Natural selection ${ }^{16}$ reflects the fact that different phenotypes have different survival and/or reproduction capacity in the environment in which they are expressed. Differential survival generates differential perpetuation of the respective genotypes. Adaptation to that characteristic increases the survival and/or reproduction of the organism that carries it, in a determined environment. Natural selection is the only known mechanism that generates adaptations by acting on naturally occurring variation, so one might say that an adaptation is a feature that evolved by natural selection (Futuyma \& Kirkpatrick, 2017). Two phenomena could influence natural selection: developmental processes and niche construction.

Developmental processes ${ }^{17}$, based on features of the genome that may be specific to a particular group of organisms, can influence the range of traits on which natural selection can act (Laland et al., 2015).

Niche construction ${ }^{18}$ is the process whereby organisms actively modify their environment and consequently modify their evolutionary niches (Odling-Smee et al., 2003).

Natural selection and genetic drift generate and modify biodiversity. That diversity is not a continuum, because a reduction of the genetic interchange ${ }^{19}$ between populations (which usually generates reproductive isolation) leads to speciation ${ }^{20}$ and to the formation of new species (Coyne \& Orr, 2004).

The definition of a species ${ }^{21}$ is very controversial (Crisci, 1981), and it has been defined in many ways for plants, animals, and microorganisms (Van Regenmortel, 1997). The most widely used, but not uncontested, criterion is the biological concept of species: a group of natural, genetically similar, interfertile populations that are reproductively isolated from other such groups (Mayr, 1970).

Speciation, therefore, is responsible for the discontinuities we observe in the diversity of life - that is, the absence of a smooth continuum in life's history. These discontinuities range from the species level (microevolution) to higher-ranking taxa (macroevolution) (Futuyma \& Kirkpatrick, 2017). Macroevolutionary changes occur with the appearance of characteristics that distinguish large groups ${ }^{22}$, such as mammals, insects, or flowering plants. They are changes that occur on a geological timescale (Jablonski, 2007). Macroevolution includes two schools of thought: gradualism and saltationism.

Gradualism $^{23}$ proposes that macroevolution results from the accumulation of small modifications throughout geological periods. The only difference between macroevolution and microevolution would then be the amount of time in which they elapse. Macroevolution, in this view, is a simple extension in time of microevolution.

Saltationism ${ }^{24}$, on the other hand, proposes that macroevolution includes processes that operate only at macroevolutionary levels. For example, large changes in chromosomes (macromutations) would give rise to very different organisms, which would adapt to new ways of life and generate differences between large groups.
One can resolve the binary distinction between gradualism and saltationism with the following argument: The evolutionary forces of microevolution work and are responsible for most of the large groups we see today. In the long history of life, however, there have been occasional occurrences of unique events that have had great consequences (Grant, 1977). An example of the last type is the evolutionary event by which a symbiotic bacterium was transformed into mitochondria of the cells of most other living beings (Margulis, 1998).

A special case of evolution is that produced by human manipulation such as genetic engineering ${ }^{25}$, also called genetic modification or genome editing. It is the direct manipulation of an organism's genome using biotechnology to produce genetically modified organisms (Vanloqueren \& Baret, 2009). To the extent that those changes are transmitted to subsequent generations, the possibility exists to alter the evolutionary trajectory of the species in question. That possibility is one of the vexing challenges inherent in the now pervasive application of CRISPRbased genetic editing (Dickinson \& Goldstein, 2016; Winblad \& Lanner, 2017).

\section{O Summary}

A concept map of evolutionary biology is a way to promote meaningful learning in biology. In this case, the concept map is an educational tool that generates a context of ideas around every main concept of the subject in an introductory road map to biological evolution.

Biological evolution is a great and stirring account of life on Earth and of human origins within it. It speaks of our connectedness to the rest of life on Earth and invokes our stewardship of our planet and its biodiversity. Biological evolution also can be inspirational by exposing students to the wonders of nature, such as flowers that attract pollinators by mimicking females, deep-sea fish that can swallow prey larger than themselves, and snakes that can strike mammalian prey in darkness by sensing their body heat. Exposure to evolutionary theory concerns not merely the facts of natural selection, common ancestry, homology, or speciation, but also the amazing array of things that organisms do by virtue of their adapted states (Douglas Futuyma, Stony Brook University, personal communication, June 6, 2016).

But there is something else important about the study of evolutionary theory: it causes us to engage with one of the most impressive and far-reaching achievements of the human intellect, and it is evolution itself that has provided us with the intellectual capacity to apprehend our own history and our place in the biosphere.

\section{O Acknowledgments}

We acknowledge Douglas Futuyma, Elián Guerrero, and Edgardo Ortiz-Jaureguizar for their useful comments on a first draft of the concept map. Those faults that remain are entirely our responsibility. Piero Marchionni and Mary Rose Stoltz provided technical assistance. The reviewers are also acknowledged for their useful comments and suggestions. 


\section{References}

Almond, R.G., Mislevy, R.J., Steinbero, L.S., Yan, D. \& Williamson, D.M. (2015). Bayesian Networks in Educational Assessment. New York: Springer.

Andrews, K., Crisci, J.V., Drexler, E., Osborne, K.W., Pultorak, R.W. \& Sigstedt, J. (2002). Climbing the Tree of Life: Taxonomy and Phylogeny for High School Biology. [CD-ROM for PC \& MAC. Supplemental, standards-based learning activities for high school biology; Interactive, inquiry-oriented activities with videos, animations, simulations, and printable documents; Off-computer research; Individual and collaborative learning; Teacher's implementation guide.] Colorado Sprinģs, CO: Biological Sciences Curriculum Study.

Apodaca, M.J., Crisci, J.V. \& Katinas, L. (2015a). Andean oriģin and diversification of the genus Perezia, an ancient-lineage of Asteraceae. Smithsonian Contributions to Botany, 102, 1-28.

Apodaca, M.J., Crisci J.V. \& Katinas, L. (2015b). Las provincias fitogeográficas de la República Arogentina: definición y sus principales áreas proteģidas. In R.R. Casas \& G.F. Albarracín (Eds.), El Deterioro del Suelo y del Ambiente en la Arǵentina (pp. 79-101). Buenos Aires, Argentina: Fundación para la Educación, la Ciencia y la Cultura, FECIC.

Ausubel, D.P., Novak, J.D. \& Hanesian, H. (1978). Educational Psycholoǵy: A Coǵnitive View. New York, NY: Holt, Rinehart, \& Winston.

Barreda, V.D., Palazzesi, L., Tellería, M.C., Katinas, L., Crisci, J.V., Bremer, K., et al. (2010). Eocene Patagonia fossils of the daisy family. Science, 329, 1621.

Baum, D.A. \& Smith, S.D. (2012). Tree Thinking: An Introduction to Phylogenetic Biology. Greenwood Village, CO: Roberts.

Charlesworth, D., Barton, N.H. \& Charlesworth, B. (2017). The sources of adaptive radiation. Proceedings of the Royal Society B, 284, 20162864.

Coyne, J.A. (2009). Why Evolution Is True. New York, NY: Penguin.

Coyne, J.A. \& Orr, A. (2004). Speciation. Sunderland, MA: Sinauer Associates.

Crisci, J.V. (1981). La especie: realidad y conceptos. Symposia, VI Jornadas Arǵentinas de Zoología, La Plata (pp. 21-32).

Crisci, J.V. (1982). Parsimony in evolutionary theory: law or methodological prescription? Journal of Theoretical Biology, 97, 35-41.

Crisci, J.V. (2006). One-dimensional systematist: perils in a time of steady progress. Systematic Botany, 31, 215-219.

Crisci, J.V. (2008). La barbarie del "especialismo" en un tiempo de extinciones. Anales de la Academia Nacional de Agronomía y Veterinaria, 62, 97-07.

Crisci, J.V. \& Katinas, L. (2009). Darwin, historical biogeography, and the need of overcoming binary opposites. Journal of Biogeography, 36, 1027-1031.

Crisci, J.V. \& Katinas, L. (2011). Taking biodiversity to school. In B. Figueroa (Ed.), Biodiversity Conservation in the Americas: Lessons and Policy Recommendations (pp. 471-506). Santiago, Chile: Editorial FENUniversidad de Chile.

Crisci, J.V., Katinas, L., Mclnerney, J.D. \& Apodaca, M.J. (2014). Taking biodiversity to school: systematics, evolutionary biology, and the nature of science. Systematic Botany, 39, 1-4.

Crisci, J.V., Katinas, L. \& Posadas, P. (2003). Historical Biogeography: An Introduction. Cambridge, MA: Harvard University Press.

Crisci, J.V., Mclnerney, J.D. \& McWethy, P.J. (1993). Order and Diversity in the Living World: Teaching Taxonomy and Systematics in Schools. Hanover, PA: Sheridan Press.

Crisci, J.V., Sala, O., Katinas, L. \& Posadas, P. (2006). Bridģing historical and ecological approaches in biogeography. Australian Systematic Botany, $19,1-10$.

Crisci, J.V. \& Stuessy, T.F. (1980). Determining primitive character states for phylogenetic reconstruction. Systematic Botany, 5, 112-135.
Darwin, C. (1859). On the Origin of Species [facsimile of the first edition, 2001]. Cambridge, MA: Harvard University Press.

Dickinson, D.J. \& Goldstein, B. (2016). CRISPR-based methods for Caenorhabditis elegans gुenome enģineeringु. Genetics, 202, 885-901.

Dobzhansky, T. (1973). Nothing in biology makes sense except in the light of evolution. American Biology Teacher, 35, 125-129.

Felsenstein, J. (2004). Inferring Phylogenies. Sunderland, MA: Sinauer Associates.

Futuyma, D.J. (2017). Evolutionary biology today and the call for an extended synthesis. Interface Focus, 7, 20160145.

Futuyma, D.J. \& Kirkpatrick, M. (2017). Evolution, 4th ed. Sunderland, MA: Sinauer Associates.

Gherardi, L. \& Sala, O.E. (2015). Enhanced precipitation variability decreases grass- and increases shrub-productivity. Proceedings of the National Academy of Sciences USA, 112, 12735-12740.

Grant, V. (1977). Oróanismic Evolution. San Francisco, CA: Freeman.

Graur, D. \& Li, W.H. (2000). Fundamentals of Molecular Evolution, 2nd ed. Sunderland, MA: Sinauer Associates.

Hall, B.K. (1994). Homology: The Hierarchical Basis of Comparative Biology. San Diego, CA: Academic Press.

Hamilton, M.B. (2009). Population Genetics. Chichester, UK: Wiley-Blackwell.

Hillis, D.M. (2010). Phylogenetic progress and applications of the tree of life. In M.A. Bell, D.J. Futuyma, W.F. Eanes \& J.S. Levinton (Eds.), Evolution since Darwin: The First 150 Years (pp. 421-450). Sunderland, MA: Sinauer Associates.

Huxman, T.E., Smith, M.D., Fay, P.A., Knapp, A.K., Shaw, M.R., Loik, M.E., et al. (2004). Convergence across biomes to a common rain-use efficiency. Nature, 429, 651-654.

Jablonka, E. \& Raz, G. (2009). Transogenerational epiggenetic inheritance: prevalence, mechanisms, and implications for the study of heredity and evolution. Quarterly Review of Biology, 84, 131-176.

Jablonski, D. (2007). Scale and hierarchy in macroevolution. Paleontoloǵy, 50, 87-109

Jobbáogy, E.G. \& Sala, O.E. (2014). The imprint of crop-choice on ģlobal nutrient needs. Environmental Research Letters, 9(8).

Katinas, L. \& Crisci, J.V. (2000). Cladistic and biogeographic analyses of the genera Moscharia and Polyachyrus (Asteraceae, Mutisieae). Systematic Botany, 25, 33-46.

Katinas, L., Crisci, J.V., Hoch, P., Tellería, M.C. \& Apodaca, M.J. (2013). Transoceanic dispersal and evolution of early composites (Asteraceae). Perspectives in Plant Ecology, Evolution and Systematics, 15, 269-280.

Kong, Y., Thawani, A., Anderson, T. \& Pelaez, N. (2017). A model of the use of evolutionary trees (MUET) to inform $\mathrm{K}-14$ biology education. American Biology Teacher, 79, 81-99.

Laland, K.N., Uller, T., Feldman, M., Sterelny, K., Muller, G. B., Moczek, A., et al. (2014). Does evolutionary theory need a rethink? Point: yes, urgently. Nature, 514, 161-164.

Laland, K.N., Uller, T., Feldman, M.W., Sterelny, K., Müller, G.B., Moczek, et al. (2015). The extended evolutionary synthesis: its structure, assumptions and predictions. Proceedings of the Royal Society B, 282, 20151019.

Lomolino, M.V., Riddle, B.R., Whittaker, R.J. \& Brown, J.H. (2010). Biogeography, 4th ed. Sunderland, MA: Sinauer Associates.

Margulis, L. (1998). Symbiotic Planet: A New Look at Evolution. Amherst, MA: Science Writers.

Mayr, E. (1970). Population, Species and Evolution: An Abridgment of Animal Species and Evolution. Cambridge, MA: Harvard University Press.

McInerney, J.D. (1989). Human ecology: restoring life to the biology curriculum. In W.G. Rosen (Ed.), High-School Biology Today and Tomorrow (pp. 117-130). Washington, DC: National Academy Press. 
McInerney, J.D. (2009). La enseñanza de la evolución siģlo y medio después del origen de las especies. Ciencia Hoy, 19(113), 76-83.

National Academy of Sciences (1998). Teaching about Evolution and the Nature of Science. Washinģton, DC: National Academy Press.

Nehm, R.H., Poole, T.M., Lyford, M.E., Hoskins, S.G., Carruth, L., Ewers, B.E. \& Colberg, P.J.S. (2009). Does the segregation of evolution in biology textbooks and introductory courses reinforce students' faulty mental models of biology and evolution? Evolution: Education and Outreach, 2, 527-532.

NGSS Lead States (2013). Next Generation Science Standards: For States, by States. Washington, DC: National Academy Press.

Noble, D. (2015). Evolution beyond neo-Darwinism: a new conceptual framework. Journal of Experimental Biology, 218, 7-13.

Novak, J.D. (2002). Meaningful learning: the essential factor for conceptual change in limited or inappropriate propositional hierarchies leading to empowerment of learners. Science Education, 86, 548-571.

Novak, J.D. (2010). Learning, Creating, and Using Knowledge: Concept Maps as Facilitative Tools in Schools and Corporations, 2nd ed. London, UK: Routledgुe.

Odling-Smee, F.J., Laland, K.N. \& Feldman, M.W. (2003). Niche Construction: The Neglected Process in Evolution.Princeton, NJ: Princeton University Press.

Pascual, R. \& Ortiz-Jaureguizar, E. (2007). The Gondwanan and South American episodes: two major and unrelated moments in the history of the South American mammals. Journal of Mammalian Evolution, 14, 75-137.

Pianka, E.R. (2011). Evolutionary Ecology, 7th ed. [eBook.] https://books. google.com.ar/books?hl=de \& $\mid r=\& i d=$ giFL5bonGhQC \& oi=fnd \& pq= PAl \& ots=NB4SwlwOlr \& sig=U-bkNH21Glf2ø33GECpnbYc3r0M \& redir_esc $=y \# v=$ onepage \& $q \& f=f a l s e$.

Ridley, M. (2004). Evolution, 3rd ed. Oxford, UK: Blackwell.

Sala, O.E. (2001). Price put on biodiversity. Nature, 412, 34-36.

Sala, O.E. (2003). (Almost) all about biodiversity. Science, 299, 1521.

Sala, O.E. (2016). How scientists can help end the land-use conflict. BioScience, 66, 915.

Templeton, A.R. (2006). Population Genetics and Microevolutionary Theory. Hoboken, NJ: Wiley.
Vanloqueren, G. \& Baret, P. V. (2009). How agricultural research systems shape a technological regime that develops genetic enģineering but locks out agroecological innovations. Research Policy, 38, 971-983.

Van Regenmortel, H.V. (1997). Viral species. In M.F. Claridģe, H.A. Dawah \& M.R. Wilson (Eds.), Species: The Units of Biodiversity (pp. 17-24). London, UK: Chapman \& Hall.

West-Eberhard, M.J. (2003). Developmental Plasticity and Evolution. Oxford, UK: Oxford University Press.

Winblad, N. \& Lanner, F. (2017). Biotechnology: at the heart of gene edits in human embryos. Nature, 548, 398-400.

Wray, G.A., Futuyma, D.A., Lenski, R.E., MacKay, T.F.C., Schluter, D., Strassman, J.E. \& Hoekstra, H.E. (2014). Does evolutionary biology need a rethink? Counterpoint: no all is well. Nature, 514, 161-164.

Wyse Jackson, P.N. (2010). Introducing Paleontology: A Guide to Ancient Life. Edinburgh, UK: Dunedin Academic Press.

Zenk, F., Loeser, E., Schiavo, R., Kilpert, F., Bogdanović, O. \& Iovino, N. (2017). Germ line-inherited H3K27me3 restricts enhancer function during maternal-to-zygotic transition. Science, 357, 212-216.

MARÍA JOSÉ APODACA (apodaca@fcnym.unlp.edu.ar) is a researcher with a focus on biogeography and evolution, División Plantas Vasculares, Museo de La Plata, Universidad Nacional de La Plata, Paseo del Bosque s/n. 1900, La Plata, Arogentina. JOSEPH D. MCINERNEY (mcinerney. joseph1@gmail.com) is a past president of the National Association of Biology Teachers, a former director of the Biological Sciences Curriculum Study, and former Executive Vice President the American Society of Human Genetics, Lutherville, Maryland 21093. OSVALDO E. SALA (osvaldo. sala@asu.edu) is Julie A. Wrigley Professor the School of Life Sciences and School of Sustainability, Director Global Drylands Center, Arizona State University, Tempe, Arizona 85287-4501, his research focus on ecology and biodiversity. LILIANA KATINAS (katinas@fcnym.unlp.edu.ar) is a professor of biogeography and plant morphology and researcher at División Plantas Vasculares, Museo de La Plata, Universidad Nacional de La Plata, Paseo del Bosque s/n. 1900, La Plata, Arģentina. JORGE V. CRISCI (crisci@fcnym. unlp.edu.ar) is an emeritus professor and a researcher on biogeography and evolution, División Plantas Vasculares, Museo de La Plata, Universidad Nacional de La Plata, Paseo del Bosque s/n. 1900, La Plata, Argentina.

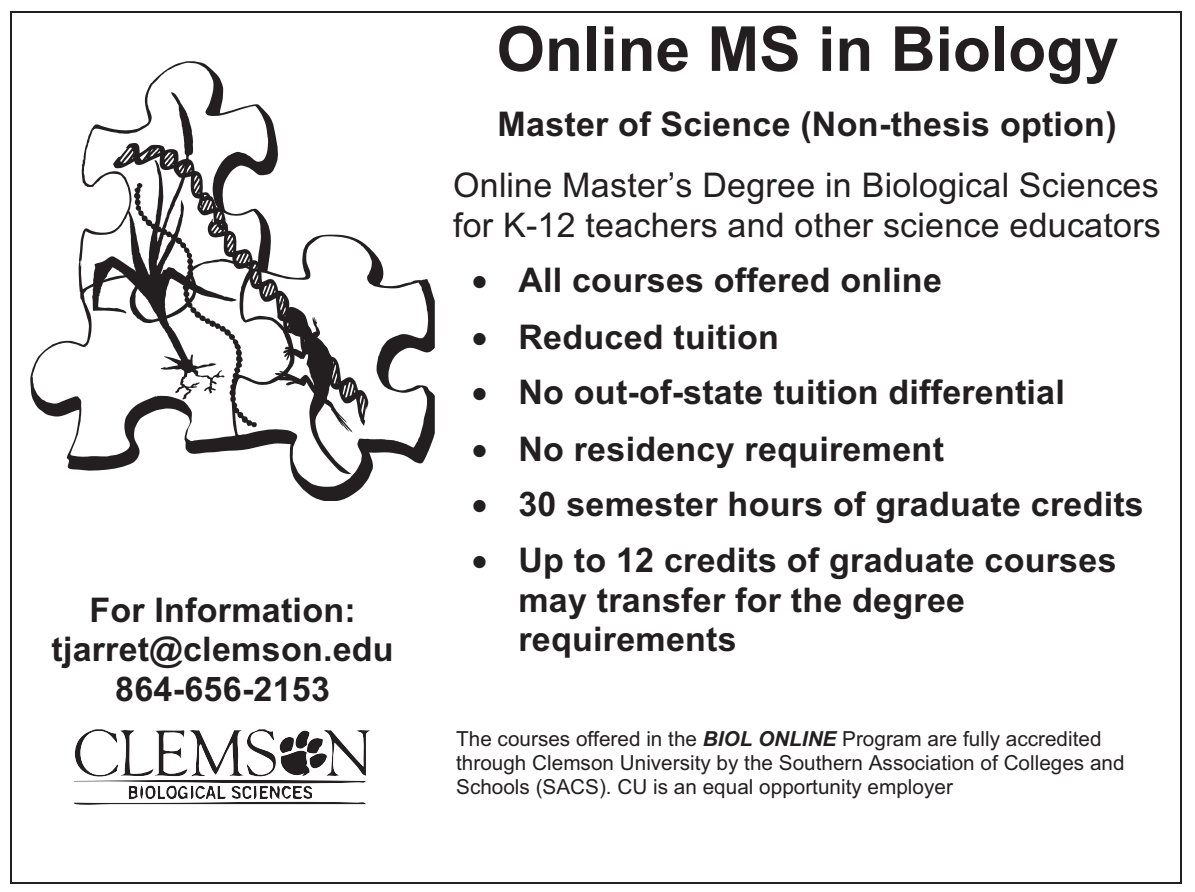

